\title{
Pollen feeding habits of Chrysoperla carnea s.l. adults in the olive grove agroecosystem
}

\author{
María Villa ${ }^{\mathrm{a}}$, Iana Somavilla ${ }^{\mathrm{b}}$, Sónia A.P. Santos ${ }^{\mathrm{c}, \mathrm{d}}$, José António López-Sáez ${ }^{\mathrm{e}}$, \\ José Alberto Pereira ${ }^{a}$, \\ ${ }^{a}$ Centro de Investigação de Montanha (CIMO), ESA, Instituto Politécnico de Bragança, Campus Santa Apolónia, 5300-253 Bragança, Portugal \\ ${ }^{\mathrm{b}}$ Universidade Federal de Santa Maria, Centro de Ciências Rurais, Departamento de Fitotecnia, 1000, 97105-900 Bairro Camobi, Santa Maria, Brazil \\ c CIQuiBio, Barreiro School of Technology, Polytechnic Institute of Setúbal, Rua Américo da Silva Marinho, 2839-001 Lavradio, Portugal \\ ${ }^{\mathrm{d}}$ LEAF, Institute of Agronomy, University of Lisbon, Tapada da Ajuda, 1349-017 Lisboa, Portugal \\ ${ }^{\mathrm{e}}$ GI Arqueobiología, Instituto de Historia, CCHS, CSIC, Albasanz 26-28, 28037 Madrid, Spain
}

A R T I C L E I N F O

\section{Keywords:}

Lacewings

Feeding habits

Non-crop vegetation

Conservation biological control

Resource selection

\begin{abstract}
A B S T R A C T
Chrysoperla carnea s.l. (Stephens) larvae are important natural enemies in agroecosystems. However, adults feed on honeydew excreted by hemipterans, and pollen and nectar from flowering plants. Pollen is essential for egg production, but to our knowledge, the pollen diet of $C$. carnea in perennial crops has never been addressed. In this work, the objective was to study the diversity and potential selection of pollen types consumed by $C$. carnea in the olive grove agroecosystem. For this study, C. carnea adults were captured from April to December of 2012 and 2013, and simultaneously, inventories of the plant diversity were obtained in olive orchards and adjacent scrubland and herbaceous patches. The pollen types contained in C. carnea guts were identified by microscopy and compared with the pollen types in the environment using Jacobs`s second selection index. The results indicated that (i) C. carnea females and males captured in the olive tree canopy visited scrub and herbaceous vegetation patches; (ii) they fed on different anemophilous and entomophilous pollen types from tree and scrub (Olea europaea, Fabaceae, Pinaceae, Cistaceae or Ericaceae) and herbaceous (Asteraceae, Apicaceae, Brassicaceae, Poaceae, Rumex type or Plantago type) strata; and (iii) adults fed not only on flowers but also on pollen settled on vegetation surfaces. Here, we demonstrated that $C$. carnea could benefit not only from the diversity of entomophilous pollen during the plant flowering periods but also from other pollens that could remain in the environment in different periods. This has important implications for the management of the floral diversity adjacent to the crop.
\end{abstract}

\section{Introduction}

Conservation biological control seeks to maintain or enhance resources in the crop environment to improve the action of natural biological control agents (Landis et al., 2000). Therefore, understanding how and which resources natural enemies use, as well as the relevance of those resources, for the success of control agents becomes a milestone in biological control. It is assumed that a species will select resources that better satisfy its living requirements and that the quantity of a resource utilized by an animal may change with the quantity available to the animal (Manly et al., 2002). Flowering plants are important resources for many entomophagous insects because they rely on floral food during some stages of their life cycle (Wäckers and van Rijn, 2012). Thus, a lower plant biodiversity in the environment could lead to a poor diet for natural enemies. However, only increasing the botanical diversity is not enough to enhance the abundance of natural enemies: the right flowering plants must be selected (Wäckers and van Rijn, 2012).

Chrysopidae (Neuroptera) is a family of common natural enemies in many crop agroecosystems; Chrysoperla carnea s.l. (Stephens) is one of the most important species. Their larvae are generalist predators, while the adults feed on sugary liquids, such as honeydew, produced by hemipteran insects and nectar and pollen from flowers (Canard, 2001). Chrysoperla carnea presents an important ecological versatility that facilitates the colonization of multiple habitats (Monserrat and Marín, 1994), and previous work suggested that chrysopids are attracted by large patches of flowering plants (Villenave et al., 2006). Moreover, food of unsuitable quantity and quality restricts individuals in a

\footnotetext{
* Corresponding author.

E-mail address: jpereira@ipb.pt (J.A. Pereira).
} 
quiescence state and retards reproductive activity in the beginning of spring (Principi, 1991), and different flowering plants cause different reproductive and survival performances in C. carnea (van Rijn et al., 2012; Villa et al., 2016a; Resende et al., 2017). Proteinaceous diets are essential for egg production in chrysopids (Villa et al., 2016a), and proteins in the field are likely provided by pollen from flowers. Thus, an increase in floral resources may have a positive impact on chrysopid populations by increasing the survival and reproduction possibilities.

Analysis of pollen grains within the gut of insects can reveal the habitats and/or plants that they visit, their movements, what they eat, and their dispersal patterns throughout the cropping system (Jones, 2014). Combinations of pollen analyses with inventories of richness and abundant flowering plants can address the importance of plant species for insects (Villa et al., 2016b). Few studies have addressed the consumption of pollen by chrysopids by the analysis of pollen grains within guts (Villenave et al., 2005, 2006; Medeiros et al., 2010; Nunes Morgado et al., 2014), but to our knowledge, no studies have been carried out in a perennial crop. Villenave et al. (2006) evaluated the selection of plants surrounding the crop and concluded that pollen was consumed according to its availability. Medeiros et al. (2010), in vegetable crops (onion, carrot, broccolis, cucumber and garlic) surrounded by Asteraceae, Poaceae and a riparian forest, found that the pollen consumed by $C$. externa belonged mainly to the Poaceae family. In a greenhouse, Nunes Morgado et al. (2014) compared pollen in the guts of Chrysoperla agilis Henry with the concurrently flowering plants and found that 14 out of 26 species were consumed, and the Plantaginaceae pollen type dominated, followed by Asteraceae and Poaceae pollen types. Both studies performed by Medeiros et al. (2010) and Nunes Morgado et al. (2014) addressed the consumption of pollen grains but did not analyse the selection of plants.

The olive tree (Olea europaea L.) is a perennial crop typically cultivated in Mediterranean regions; several pests can cause important economic damage to the crop, such as the olive moth, Prays oleae (Bernard) (Lepidoptera: Praydidae), which can be found in Europe, northern Africa and Asia (CAB International). Chrysopid larvae are considered important natural enemies of this pest (Arambourg, 1984; Neuenschwander and Michelakis, 1980; Porcel, 2012; Paredes et al., 2015), and a synchrony between C. carnea and P. oleae populations was observed by Bento (1999). Moreover, chrysopid larvae can prey on immature stages of the secondary pests of the olive tree, Saissetia oleae (Hemiptera: Coccidae) (Olivier) (Arambourg, 1984) and Euphyllura olivina (Costa) (Hemiptera: Psyllidae) (Pantaleoni et al., 2001). Despite its importance, feeding habits of adult chrysopids in the olive grove agroecosystem are poorly known. Porcel et al. (2013) found that $C$. carnea adults were positively influenced by the presence of weed cover, and McEwen and Ruiz (1994) found an association between non-crop vegetation and chrysopid eggs in the olive grove agroecosystem.

In this context, the objective of this work was to identify the plant species exploited by C. carnea adults throughout the year. Through the observation of pollen in guts, we analysed whether C. carnea preferentially consumed herbaceous or woody plants and whether they exploited several patches in surrounding agricultural areas to determine the importance of botanical diversity in supplying food resources for $C$. carnea.

\section{Materials and Methods}

\subsection{Study areas}

Field studies were conducted in the Mirandela municipality, northeastern Portugal, during 2012 and 2013 in three olive groves (1: $41^{\circ} 29^{\prime} 16^{\prime \prime} \mathrm{N},-7^{\circ} 07^{\prime} 34^{\prime \prime} \mathrm{W}$; 2: $41^{\circ} 32^{\prime} 8^{\prime \prime} \mathrm{N},-7^{\circ} 07^{\prime} 29^{\prime \prime} \mathrm{W} ; 3: 41^{\circ} 34^{\prime} 12^{\prime \prime} \mathrm{N}$, $-7^{\circ} 09^{\prime} 59^{\prime \prime} \mathrm{W}$ ) and two surrounding field areas (an herbaceous vegetation patch and a scrubland) next to each olive grove. Selection of the study sites was described by Villa et al. (2016b).

Additionally, to estimate the percentage of area covered by olive crops, herbaceous vegetation and scrubland in the C. carnea habitat, nine olive groves located in Mirandela Municipality were selected $\left(41^{\circ} 33^{\prime} 34.39^{\prime \prime} \mathrm{N}, \quad 7^{\circ} 05^{\prime} 37.17^{\prime \prime} \mathrm{W} ; \quad 41^{\circ} 34^{\prime} 12.25^{\prime \prime} \mathrm{N}, \quad 7^{\circ} 09^{\prime} 59.01^{\prime \prime} \mathrm{W}\right.$; $41^{\circ} 25^{\prime} 44.91^{\prime \prime} \mathrm{N}, \quad 7^{\circ} 12^{\prime} 20.71^{\prime \prime} \mathrm{W} ; \quad 41^{\circ} 33^{\prime} 00.58^{\prime \prime} \mathrm{N}, \quad 7^{\circ} 08^{\prime} 39.92^{\prime \prime} \mathrm{W}$; $41^{\circ} 32^{\prime} 17.31^{\prime \prime} \mathrm{N}, \quad 7^{\circ} 05^{\prime} 43.89^{\prime \prime} \mathrm{W} ; \quad 41^{\circ} 29^{\prime} 16.86^{\prime \prime} \mathrm{N}, \quad 7^{\circ} 07^{\prime} 34.02^{\prime \prime} \mathrm{W}$; $41^{\circ} 33^{\prime} 01.46^{\prime \prime} \mathrm{N}, \quad 7^{\circ} 6^{\prime} 31.57^{\prime \prime} \mathrm{W} ; \quad 41^{\circ} 26^{\prime} 38.09^{\prime \prime} \mathrm{N}, \quad 7^{\circ} 13^{\prime} 28.69^{\prime \prime} \mathrm{W}$; $\left.41^{\circ} 29^{\prime} 30.02^{\prime \prime} \mathrm{N}, 7^{\circ} 15^{\prime} 28.72^{\prime \prime} \mathrm{W}\right)$.

\subsection{Availability of pollen types in the environment}

First, flowering plant inventories were carried out in each patch every week from the last week of March through June and every other week during July and August in 2012 and 2013 following the methodology described in Villa et al. (2016b): five flowering plant inventories were carried out in circular plots of $25 \mathrm{~m}^{2}$ (olive groves and herbaceous patches) and three were in circular plots of $100 \mathrm{~m}^{2}$ (scrubland patches). Due to the larger size of the plants (trees and shrubs) in the scrublands, larger plots were required to record all of the species. Hence, there was a total of 39 plant inventories in each sampling date for characterizing the plant community of the olive grove agroecosystem. The percentage ground cover for each flowering plant species was recorded following the Daubenmire cover scale modified by Bailey (Mueller-Dombois and Ellenberg, 1974), i.e., class 1 for $0-1 \%$ cover; class 2 for $1-5 \%$ cover; class 3 for $5-25 \%$ cover; class 4 for $25-50 \%$ cover; class 5 for $50-75 \%$ cover; class 6 for $75-95 \%$ cover; and class 7 for $95-100 \%$ cover. Data presented in Villa et al. (2016b) were used for flowering plant inventories from September to December. Plant species were grouped by pollen type for further analysis. Grouping was based on similarities related to the morphology of the pollen grains: family, genus, species, or type (grouping several species or genus).

After all of the vegetation areas had been individually assessed, the percentage of area covered by olive crops, herbaceous vegetation and scrubland in the $C$. carnea habitat, which typically flight through many kilometres (Duelli, 1984), was estimated. This estimation was made considering several areas across the region (see Section 2.1). A circular area with a diameter of $1000 \mathrm{~m}$ was nested around each olive grove. Land-use classes occurring across study sites were obtained from "Carta de Uso e Ocupação do Solo de Portugal Continental para 2007" (COS, 2007), and the percentage of olive crops, scrublands and herbaceous vegetation patches was calculated using the software Patch Analyst for ArcGIS, version 9.3.1 (ESRI, Redlands, California).

The availability of each pollen type in the environment was estimated as $m_{i}=\sum m_{i j}$ where $i$ is the category of pollen type, $j$ each habitat (herbaceous scrubland and olive grove), and $m$ results from multiplying the percentage of ground covered by the pollen type $i$ in each habitat registered in the inventories and the estimated percentage of area of the same habitat for the region.

\subsection{Pollen consumed by C. carnea}

From the last week of March until the middle of December 2012 and 2013, chrysopids were captured on a weekly basis. Olive tree branches were shaken, and flying chrysopids were captured using a sweep net. The period spent collecting chrysopids was $30 \mathrm{~min}$ per grove. Collected specimens were identified at the species level, and $C$. carnea specimens were sexed and frozen at $18^{\circ} \mathrm{C}$.

The frozen $C$. carnea were thawed at room temperature, washed with $96 \%$ alcohol and vortexed for two minutes to eliminate external pollen. Chrysopids have a strong muscular diverticulum at the distal part of the oesophagus where the pollen undergoes the first breakdown being partially digested (Canard, 2001). However, for a more accurate pollen identification, an additional artificial acid digestion (with acetic anhydride and sulfuric acid) in a process known as acetolysis is recommended (see Jones, 2014) to digest proteins, lipids and insect and pollen grain debris.

The acetolysis was accomplished as follows: (i) each insect was 


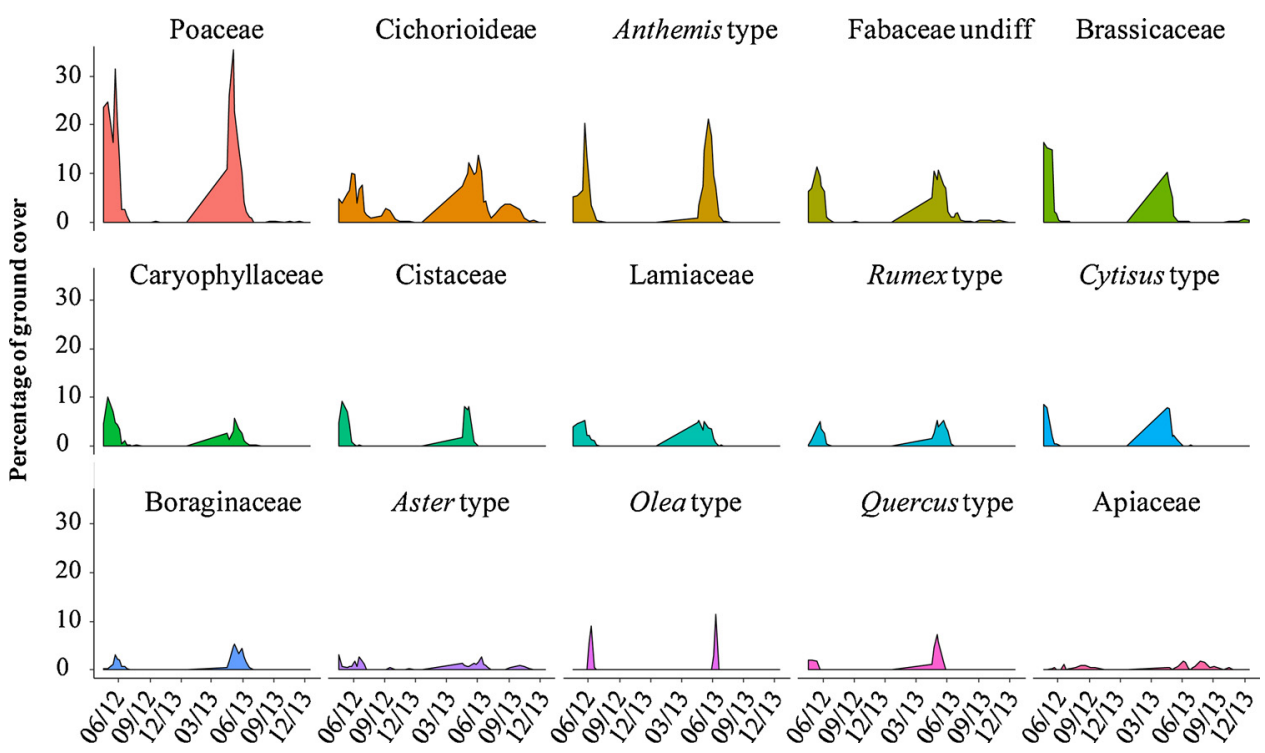

Fig. 1. Percentage of available pollen types in the olive grove agroecosystem. Blooming plants were identified in olive groves and surrounding scrublands and herbaceous patches from April to December of 2012 and 2013, and an estimation considering the percentage of land cover by each patch type (48\% of olive grove, $26 \%$ of scrubland, $15 \%$ of herbaceous patches) is shown. The most abundant pollen types are shown.

transferred individually into a $1.5 \mathrm{~mL}$ microcentrifuge tube with $0.5 \mathrm{~mL}$ of glacial acetic acid for $5 \mathrm{~min}$ to eliminate any residual water from the sample and avoid reactions with the sulfuric acid used thereafter. Then, the glacial acetic acid was discarded; (ii) the insect was smashed using a clean toothpick and, to accomplish the artificial acid digestion, $0.5 \mathrm{~mL}$ of acetolysis mixture (9:1 ratio of acetic anhydride and sulfuric acid) was added; (iii) the tubes were heated $\left(100^{\circ} \mathrm{C}\right)$ in a dry heater for $5 \mathrm{~min}$; (iv) after that, $0.5 \mathrm{~mL}$ of glacial acetic acid was added to stop the acetolysis process; (v) the samples were centrifuged for $3 \mathrm{~min}$ at $5000 \mathrm{rpm}$, and the supernatant was discarded; (vi) to clean the remaining reagents, the samples were washed three times by the addition of $0.5 \mathrm{~mL}$ of distilled water and stirring in a vortex; and (vii) then, the samples were centrifuged again (for $3 \mathrm{~min}$ at $5000 \mathrm{rpm}$ ), and the supernatant was discarded.

All reactive processes were conducted in a fume hood. Extreme caution was taken in all the processes, particularly while decanting the supernatant (see Jones, 2014) to avoid loss of pollen. Two drops of glycerin jelly:water (1:1) were added; microscopic slides were prepared with the solution, and an optical microscope was used to count and identify the pollen grains. When there were more than 5000 pollen grains, half of the slide was counted, and when there were more than 15 000 , a quarter of the slide was counted; the total number of grains was estimated thereafter. Identification was based on Valdés et al. (1987) and Moore et al. (1991) and supported by a reference pollen collection hosted at the School of Agriculture, Polytechnic Institute of Bragança. Pollen grains were grouped using the same criteria used for grouping the available pollen in the environment i.e., similarities related to the morphology of the pollen grains: family, genus, species, or type (grouping several species or genus).

\subsection{Selection index calculation}

Jacobs`s second selection index $\left(D_{i}\right)$ (Manly et al., 2002) was used to compare the consumption frequency of a species to its availability. A positive Jacobs`s index value indicates selection of the resource and a negative avoidance. This index is defined as:

$D i=\frac{O_{i}-\hat{\pi}_{i}}{O_{i}-\hat{\pi}_{i}-2 O_{i} \hat{\pi}_{i}}$

where $\mathrm{O} i$ is the proportion of used units (number of pollen grains) in category $i$ (pollen type) calculated as $\mathrm{Oi}=U_{i} / U_{+}$, (Ui: number of consumed pollen grains of pollen type $i$ by a specimen; $U_{+}$: total number of consumed pollen grains by a specimen), and $\hat{\pi}_{i}$ is the sample of the proportion of available units (percentage of ground covered) that are in pollen type $i$ calculated as $\hat{\pi}_{i}=m_{i} / m_{+}\left(m_{i}\right.$ : availability of pollen type $i$, previously estimated; $m_{+}$: percentage of total available pollen, i.e., sum of the percentages of all available pollen types for each date).

Thus, $D_{i}$ was calculated for each specimen using the corresponding $\hat{\pi}_{i}$ registered at the date (a total of 77 dates) of its capture. Then, the means of $D_{i}$ and $O_{i}$ for both males and females captured during the spring, the summer and the autumn of 2012 and 2013 were calculated.

\subsection{Amount of pollen in male and female guts}

To analyse the amount of pollen in male and female guts, a generalized additive model (gam) with a negative binomial distribution and logarithmic link function was fitted. The number of pollen grains contained in the gut was the response variable. The sex and a smooth of Julian Day by year (to capture the non-linear relationship between pollen consumption and the sampling date) were the explanatory variables. A plot of the residuals versus each covariate was used to investigate model misfit (Zuur, 2012). The gam function from the "mgcv" package (Wood, 2011) in R (R Core Team, 2016) was used.

\section{Results and discussion}

\subsection{Flowering plant inventories and pollen types identified in the C. carnea} gut

Considering the flowering plant inventories, a total of 257 plant species (172 in herbaceous patches, 169 in olive groves and 180 in scrublands) belonging to 47 families were identified. The total number of plant species was grouped by pollen types resulting in 65 groups and was used to compare them with the pollen found in the $C$. carnea guts (the most abundant pollen types in the environment are shown in Fig. 1).

In this study, a total of 290 specimens of $C$. carnea were captured in 2012 and 2013. In the gut of 190 specimens, 44 pollen types were identified (with a mean of 4.42 pollen types per adult), and the total pollen grains were between 0 and 62,533. Although the number of pollen grains consumed in the spring was higher than that in the summer and autumn of both years (Fig. 2), the majority of $C$. carnea adults contained pollen in their guts in all seasons.

Of the 145 females analysed, 93.79\% consumed pollen, and of the 145 males analysed, $95.52 \%$ had pollen grains in their guts. The richness of pollen types consumed by females and males was similar, but in general, the number of pollen grains consumed by females was significantly higher than the number of pollen grains consumed by males 


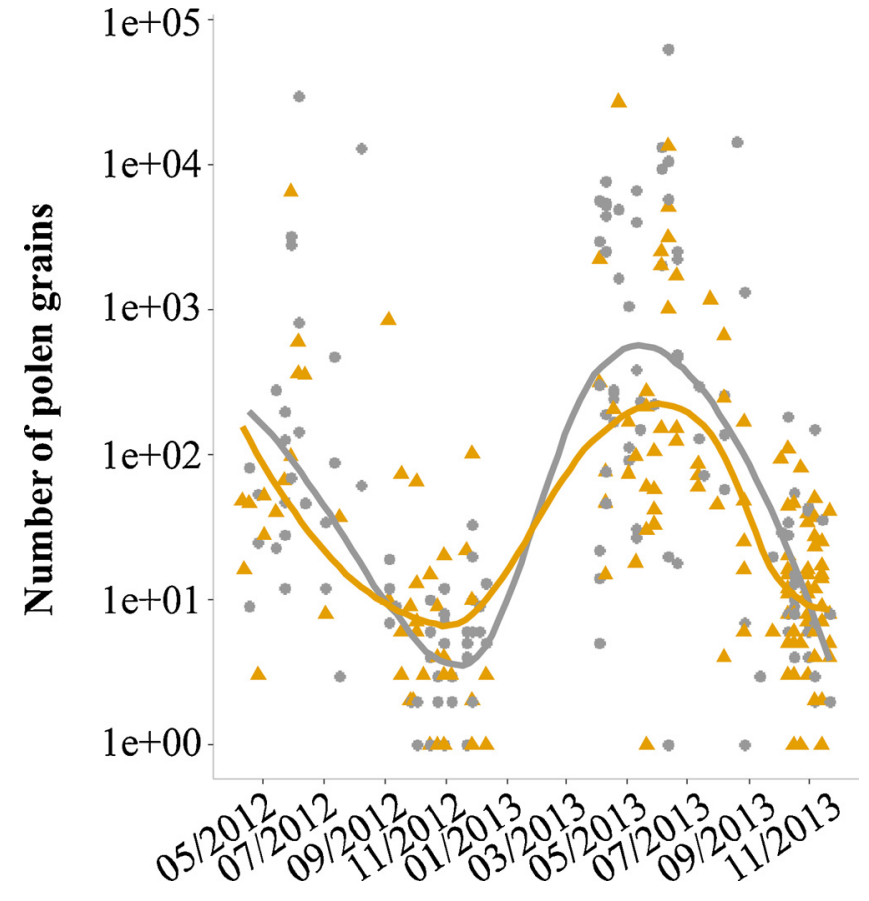

Fig. 2. Number of pollen grains consumed by females $(\square)$ and males $(\Delta)$ of Chrysoperla carnea $s l$ in the olive grove agroecosystem from April to December of 2012 and 2013. Points represent individual observations, and lines represent smooth curves (local polynomial regression method - span $=0.6$ ) of the number of pollen grains consumed during the year.

(Table 1) (estimate $=-0.490 ; \mathrm{SE}=0.19 ; \mathrm{Z}=-2.567 ; \mathrm{p}$-value $=0.01$ ) with the smoothed functions for Julian Days by year highly significant (2012: edf $=6.963 ; \chi^{2}=416.0$; p-value $<2 \mathrm{e}-16 ; 2013$ : edf $=3.188$; $\chi^{2}=181.5$; p-value $<2 \mathrm{e}-16$ ). These results differed from those obtained by Villenave et al. (2005) and Villenave et al. (2006), who observed a lower number of pollen grains consumed by Chrysoperla spp. in all seasons in a cabbage crop. Additionally, different methods used for pollen extraction (not acetolyzed in Villenave et al., 2005 and 2006) could have influenced the differences found in the results.

\subsection{Pollen selection}

In this study, several pollen types (such as Cichorioideae or Olea) resulted in a positive Jacobs`s index selection, $D_{i}$ and/or a high proportion of consumed pollen grains, $O_{i}$ (the most abundant pollen types in guts are shown in Table 2). When the selection is positive, the adults could (i) have actively searched for flowers or (ii) licked the pollen from vegetation surfaces. When the selection index is negative, this could be due to (i) the plant species being unattractive; (ii) the impossibility of finding those plant species because they are too rare (a low $\pi_{i}$ ), i.e., percentage of ground cover by that plant that would make it undetectable by C. carnea; (iii) the flowers can be closed at dusk (Villenave et al., 2006); or (iv) the percentage of ground cover by that plant species could exceed the adult needs (a high $\pi_{i}$ ).

\subsubsection{Anemophilous pollen}

Several anemophilous plants were highly consumed by $C$. carnea adults, namely, Olea, Pinaceae and Betula, from the tree stratum and Poaceae, Chenopodiaceae. Plantago type and Rumex from the herbaceous stratum (Table 2, Fig. 3).

3.2.1.1. Tree stratum. From the tree stratum, the most consumed pollen type in all seasons was Olea, ranging from 11.6 to $52.7 \%$ of the consumed pollen grains among all specimens, and although the flowering period lasted only a few days, $D_{i}$ was 1 or close to 1 for both females and males. This result indicates that $C$. carnea fed not only on pollen from flowers but also on settled pollen. The consumption of Olea pollen could be related to the fact that lacewings hide during the day in olive agroecosystems. In this agroecosystem, Olea seem to be an interesting food resource for $C$. carnea, and it could be concluded that the pollen from this tree is sufficient to feed $C$. carnea adults. However, a poor diet can negatively influence the survival and reproduction of chrysopids (Principi, 1991). Therefore, the other pollen types consumed probably had an essential role in the performance of $C$. carnea. The nutrient composition of the different pollen types can be an important aspect. For example, Liolios et al. (2016) found that Olea pollen contained $17.26 \%$ of proteins, while other species belonging to Polygonaceae, Fabaceae, Asteraceae or Brassicaceae, also consumed by $C$. carnea in the present study, presented more proteins in their composition than Olea pollen. Additionally, since the olive tree flowering period takes a few days, in an olive grove agroecosystem poor in flowering plants, the adults would rely only on settled Olea pollen for most of the season, and therefore, the insect reliance on this pollen could be deleteriously affected by strong rains or other unfavourable conditions that could remove the settled pollen. Villenave et al. (2006) also observed the consumption of crop plants (Brassicaceae, Apiaceae, Fabaceae), but in their study, the pollen consumption of crop plants occurred only during the flowering periods. In the present study, the anemophilous pollen of Pinaceae had a positive index of selection in almost all the seasons of both years for females and in the summer and the autumn of 2013 for males. This was because the Pinaceae flowering period occurred only in the spring, and $\pi_{i}$ in the summer and autumn was zero; however, the higher consumption occurred in the spring. Betula was consumed by several females and males, although it was not present in the study patches (making $D_{i}$ equal to 1 ), representing less than $1 \%$ of the consumed pollen in guts. Other works found Pinaceae and Betulaceae to be important for Chrysoperla (Villenave et al., 2005; Monserrat and DíazAranda, 1989).

3.2.1.2. Herbaceous stratum. From the anemophilous pollen in the herbaceous stratum, the Poaceae was among the most consumed and

Table 1

Number of individuals of Chrysoperla carnea females and males with and without pollen in in their guts and total number of individuals analyzed in the Spring (Spr), Summer (Sum) and Autumn (Aut) of 2012 and 2013. Richness of consumed pollen types - R, median, maximum and minimum of consumed pollen types - Mdn (MaxMin) and mean of consumed pollen grains \pm standard error $-M \pm S E$, are shown.

\begin{tabular}{|c|c|c|c|c|c|c|c|c|c|c|c|}
\hline \multirow[t]{2}{*}{ Sex } & \multirow[t]{2}{*}{ Chrysoperla carnea } & \multicolumn{3}{|c|}{2012} & \multicolumn{3}{|c|}{2013} & \multirow[t]{2}{*}{ Total } & \multirow[t]{2}{*}{$\mathrm{R}$} & \multirow[t]{2}{*}{ Mdn (Max-Min) } & \multirow[t]{2}{*}{$\mathrm{M} \pm \mathrm{SE}$} \\
\hline & & Spr & Sum & Aut & Spr & Sum & Aut & & & & \\
\hline \multirow[t]{3}{*}{ Females } & Individuals with pollen & 18 & 8 & 31 & 43 & 10 & 26 & 136 & 37 & $4(1-11)$ & $1686 \pm 541$ \\
\hline & Individuals without & 0 & 0 & 8 & 0 & 1 & 0 & 9 & & & \\
\hline & Total analyszed females & 18 & 8 & 39 & 43 & 11 & 26 & 145 & & & \\
\hline \multirow[t]{3}{*}{ Males } & Individuals with pollen & 13 & 4 & 25 & 30 & 13 & 53 & 138 & 39 & $5(1-13)$ & $546 \pm 233$ \\
\hline & Individuals without & 0 & 0 & 5 & 0 & 0 & 2 & 7 & & & \\
\hline & Total analyszed males & 13 & 4 & 30 & 30 & 13 & 55 & 145 & & & \\
\hline
\end{tabular}


Table 2

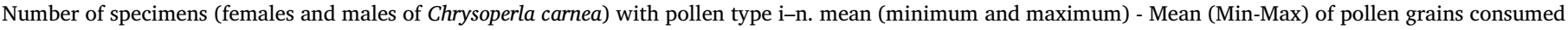

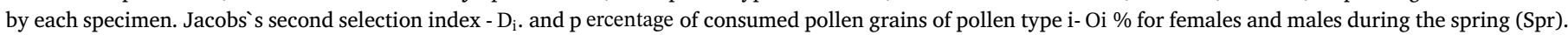

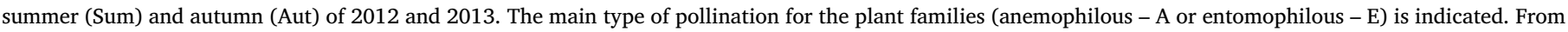
the 44 pollen types found, the most consumed types $(n=17)$ are shown.

\begin{tabular}{|c|c|c|c|c|c|c|c|c|c|c|c|c|c|c|c|c|c|}
\hline \multirow[t]{3}{*}{ Sex } & \multirow[t]{3}{*}{ Family } & \multirow[t]{3}{*}{ Pollination } & \multirow[t]{3}{*}{ Pollen type } & \multirow[t]{3}{*}{$\mathrm{n}$} & \multirow[t]{3}{*}{ M (Min-Max) } & \multicolumn{6}{|l|}{$\mathrm{Di}$} & \multicolumn{6}{|l|}{$\mathrm{Oi} \%$} \\
\hline & & & & & & \multicolumn{3}{|l|}{2012} & \multicolumn{3}{|l|}{2013} & \multicolumn{3}{|l|}{2012} & \multicolumn{3}{|l|}{2013} \\
\hline & & & & & & Spr & Sum & Aut & Spr & Sum & Aut & Spr & Sum & Aut & Spr & Sum & Aut \\
\hline \multirow[t]{17}{*}{ Females } & Apiaceae & $\mathrm{E}$ & Apiaceae & 23 & $836(1-12,800)$ & -0.9 & -0.5 & -0.7 & -0.7 & -0.7 & -0.6 & 0.3 & 17.0 & 4.9 & 2.7 & 10.0 & 4.3 \\
\hline & Asteraceae & $\mathrm{E}$ & Anthemis type & 29 & $257(1-6000)$ & -0.8 & -1.0 & -0.9 & -0.6 & -0.4 & -0.8 & 2.6 & 0.0 & 0.5 & 6.4 & 0.9 & 3.4 \\
\hline & & & Aster type & 31 & $27(1-486)$ & -0.7 & -1.0 & -0.9 & -0.4 & -0.8 & -0.6 & 0.5 & 0.0 & 2.0 & 4.4 & 0.6 & 2.0 \\
\hline & & & Cichorioideae & 38 & $131(1-4104)$ & -1.0 & -0.7 & -0.9 & -0.8 & -0.2 & -0.4 & 0.1 & 6.3 & 1.3 & 1.7 & 23.8 & 10.4 \\
\hline & Betulaceae & A & Betula & 13 & $7(1-44)$ & 1.0 & - & - & 1.0 & 1.0 & - & 0.0 & 0.0 & 0.0 & 0.2 & 0.9 & 0.0 \\
\hline & Boraginaceae & $\mathrm{E}$ & Boraginaceae & 16 & $9(1-50)$ & -1.0 & -1.0 & -0.5 & -0.8 & -1.0 & -0.9 & 0.0 & 0.0 & 0.4 & 0.5 & 0.0 & 0.5 \\
\hline & Brassicaceae & $\mathrm{E}$ & Brassicaceae & 17 & $547(1-5150)$ & -1.0 & -1.0 & -0.5 & -0.6 & -0.8 & -0.8 & 0.0 & 0.0 & 9.5 & 8.3 & 1.7 & 5.8 \\
\hline & Chenopodiaceae & $\mathrm{A}$ & Chenopodiaceae & 15 & $13(1-137)$ & 1.0 & -0.1 & 1.0 & 1.0 & 0.0 & -0.8 & 0.0 & 2.4 & 3.4 & 0.0 & 0.8 & 4.5 \\
\hline & Cistaceae & $\mathrm{E}$ & Cistaceae & 29 & $97(1-1588)$ & -0.9 & -0.3 & 1.0 & -0.4 & 1.0 & 1.0 & 2.6 & 0.1 & 4.7 & 8.4 & 0.2 & 1.5 \\
\hline & Ericaceae & $\mathrm{E}$ & Ericaceae & 31 & $4(1-40)$ & 1.0 & 1.0 & 1.0 & 1.0 & 1.0 & 1.0 & 0.6 & 1.1 & 1.2 & 0.5 & 0.2 & 0.7 \\
\hline & Fabacea & $\mathrm{E}$ & Cytisus/Genista type & 51 & $129(1-4276)$ & -0.2 & 1.0 & 1.0 & 0.1 & 1.0 & 1.0 & 9.6 & 16.4 & 17.5 & 7.2 & 0.8 & 5.9 \\
\hline & & & Fabaceae undiff. & 14 & $6(1-43)$ & -0.9 & -0.1 & -0.8 & -1.0 & -1.0 & -1.0 & 2.8 & 10.1 & 0.6 & 0.3 & 0.0 & 0.0 \\
\hline & Oleaeceae & A & Olea & 104 & $1609(1-62,520)$ & 1.0 & 1.0 & 1.0 & 1.0 & 1.0 & 1.0 & 41.8 & 24.1 & 40.2 & 40.3 & 11.6 & 46.1 \\
\hline & Pinaceae & A & Pinaceae & 49 & $14(1-108)$ & 1.0 & - & 1.0 & 0.6 & 1.0 & 1.0 & 6.9 & 0.0 & 1.2 & 7.6 & 9.6 & 1.4 \\
\hline & Plantaginaceae & A & Plantago type & 27 & $375(1-10,012)$ & -0.4 & -0.5 & -1.0 & -0.7 & 0.1 & -0.9 & 1.6 & 0.0 & 0.0 & 0.8 & 13.0 & 1.9 \\
\hline & Poaceae & A & Poaceae & 54 & $17(1-312)$ & -0.8 & 0.7 & 0.1 & -0.6 & -0.6 & -0.4 & 3.3 & 11.8 & 2.2 & 2.3 & 0.2 & 4.4 \\
\hline & Poligonaceae & A & Rumex & 27 & $42(1-225)$ & -0.5 & 1.0 & 1.0 & -0.6 & 1.0 & - & 10.2 & 1.1 & 0.4 & 4.0 & 11.3 & 0.0 \\
\hline \multirow[t]{17}{*}{ Males } & Apiaceae & $\mathrm{E}$ & Apiaceae & 23 & $45(1-755)$ & -0.7 & 0.0 & -0.8 & -0.7 & -0.5 & -0.8 & 1.0 & 23.9 & 3.0 & 0.8 & 2.8 & 2.0 \\
\hline & Asteraceae & $\mathrm{E}$ & Anthemis type & 28 & $21(1-299)$ & -0.8 & -1.0 & -1.0 & -0.4 & -0.6 & -0.8 & 1.5 & 0.0 & 0.0 & 10.0 & 0.4 & 2.0 \\
\hline & & & Aster type & 21 & $6(1-37)$ & -0.8 & -1.0 & -0.9 & -0.6 & -0.7 & -0.9 & 0.3 & 0.0 & 0.2 & 0.9 & 1.8 & 0.3 \\
\hline & & & Cichorioideae & 47 & $6(1-76)$ & -0.9 & -1.0 & -0.8 & -0.8 & -0.3 & -0.4 & 0.9 & 0.0 & 0.9 & 1.3 & 5.9 & 8.5 \\
\hline & Betulaceae & A & Betula & 10 & $4(1-10)$ & - & - & 1.0 & 1.0 & 1.0 & - & 0.0 & 0.0 & 0.0 & 0.8 & 0.6 & 0.0 \\
\hline & Boraginaceae & $\mathrm{E}$ & Boraginaceae & 12 & $14(1-80)$ & -1.0 & -1.0 & -1.0 & -0.8 & -1.0 & -1.0 & 0.0 & 0.0 & 0.0 & 2.5 & 0.0 & 0.0 \\
\hline & Brassicaceae & $\mathrm{E}$ & Brassicaceae & 7 & $3796(1-26,528)$ & -1.0 & -1.0 & -0.9 & -0.8 & -1.0 & -0.9 & 0.0 & 0.0 & 1.3 & 4.3 & 0.0 & 2.6 \\
\hline & Chenopodiaceae & A & Chenopodiaceae & 20 & $35(1-600)$ & - & -1.0 & 1.0 & 1.0 & 0.7 & -0.6 & 0.0 & 0.0 & 0.8 & 0.1 & 10.3 & 6.4 \\
\hline & Cistaceae & $\mathrm{E}$ & Cistaceae & 20 & $16(1-182)$ & -0.8 & -1.0 & 1.0 & -0.7 & _- & 1.0 & 5.3 & 0.0 & 0.5 & 6.6 & 0.0 & 2.7 \\
\hline & Ericaceae & $\mathrm{E}$ & Ericaceae & 27 & $2(1-8)$ & 1.0 & - & 1.0 & 1.0 & 1.0 & 1.0 & 1.3 & 0.0 & 4.8 & 1.2 & 0.1 & 1.1 \\
\hline & Fabaceae & $\mathrm{E}$ & Cytisus/Genista type & 44 & $16(1-259)$ & 0.2 & 1.0 & 1.0 & 0.1 & 1.0 & 1.0 & 11.1 & 2.8 & 7.0 & 7.0 & 6.3 & 2.7 \\
\hline & & & Fabaceae undiff & 17 & $8(1-57)$ & -0.9 & 0.0 & -0.5 & -1.0 & -0.8 & -0.9 & 0.5 & 2.3 & 2.9 & 0.2 & 0.2 & 0.2 \\
\hline & Oleaeceae & A & Olea & 114 & $350(1-13,456)$ & 1.0 & 1.0 & 1.0 & 1.0 & 1.0 & 1.0 & 39.2 & 52.7 & 56.0 & 41.2 & 37.0 & 45.2 \\
\hline & Pinaceae & A & Pinaceae & 43 & $7(1-52)$ & -1.0 & - & - & -0.4 & 1.0 & 1.0 & 13.6 & 0.0 & 0.0 & 3.6 & 2.6 & 0.8 \\
\hline & Plantaginaceae & A & Plantago type & 24 & 27 (1-279) & -0.8 & -1.0 & -0.1 & -0.6 & -0.3 & -0.8 & 0.1 & 0.0 & 4.8 & 0.8 & 13.9 & 1.8 \\
\hline & Poaceae & A & Poaceae & 47 & $15(1-392)$ & -0.9 & 0.4 & -0.5 & -0.4 & -0.2 & -0.7 & 2.1 & 8.6 & 2.6 & 4.6 & 3.2 & 3.0 \\
\hline & Poligonaceae & A & Rumex & 27 & $16(1-91)$ & -0.3 & -1.0 & 1.0 & -0.5 & -0.3 & 1.0 & 7.2 & 0.0 & 0.6 & 6.2 & 5.0 & 1.3 \\
\hline
\end{tabular}

presented a positive selection index during the summer and autumn of 2012 for females and the summer of 2012 for males. This family was found to be important for chrysopids in other works (Medeiros et al., 2010; Villenave et al., 2005 and 2006). Chenopodiaceae was selected by females and males during autumn 2012 and spring and summer 2013, with $O_{i} \%$ always lower than $10.3 \%$. Plantago type (Plantaginaceae) and Rumex (Polygonaceae) were consumed and generally underselected, except when they did not occur in the inventoried patches. The maximum consumption of Plantago type occurred in summer 2013 and Rumex in spring 2012 and autumn 2013.

In other studies, Chenopodiaceae were important along with Plantaginaceae, while Polygonaceae were consumed at a low percentage (Villenave et al., 2005 and 2006). Pollen grains of all these anemophilous plants, particularly when they were consumed out of their flowering periods, could have remained on vegetation surfaces where $C$. carnea could have licked them, as suggested by Wäckers and van Rijn (2012).

\subsubsection{Entomophilous pollen}

Several entomophilous plants were also highly consumed by $C$. carnea adults, namely, Cistaceae, the Fabaceae Cytisus/Genista type and Ericaceae from the bush stratum and Apiaceae, Asteraceae, Brassicaceae, Boraginaceae, and undifferentiated (undiff.) Fabaceae from the herbaceous stratum (Table 2, Fig. 3).

3.2.2.1. Bush stratum. From the bushes, Cistaceae was mainly consumed by females and males in the spring of both years, although the selection index was only positive during the autumn of both years and summer of 2013. Despite the papilionaceus shape of the flowers of Cytisus/Genista (shrub Fabaceae), their pollen type was consumed by a considerable number of males and females. This pollen type was generally selected and consumed in a high percentage in almost all sessions (Table 2). To our knowledge, this is the first record of $C$. carnea feeding on both Cistaceae and shrub Fabaceae. Ericaceae pollen (except Arbutus unedo L.) was found in adult guts in the spring and autumn of both years. Villenave et al. (2006) also found Ericaceae pollen in Chrysoperla adults.

3.2.2.2. Herbaceous stratum. Regarding the entomophilous pollen in the herbaceous stratum, the proportion of pollen of Apiaceae consumed showed more importance during the summer and in the autumn to a certain degree for both males and females. However, the selection index was always negative. Similarly, Villenave et al. (2006) found Daucus carota L. (Apiaceae) consumption with negative selection, while in laboratory experiments, $D$. carota and Foeniculum vulgare L. (Apiaceae) improved the survival and/or reproduction of C. carnea (Villa et al., 2016a; van Rijn et al., 2012). Therefore, a negative index selection may not imply unimportance for some pollen types, such as Apicaceae. Several Asteraceae pollen types (Anthemis type, Aster type and Cichorioideae) were well represented in the adult guts, particularly Cichorioideae during summer and autumn 2013. The selection index was always negative, indicating the generally high cover of 


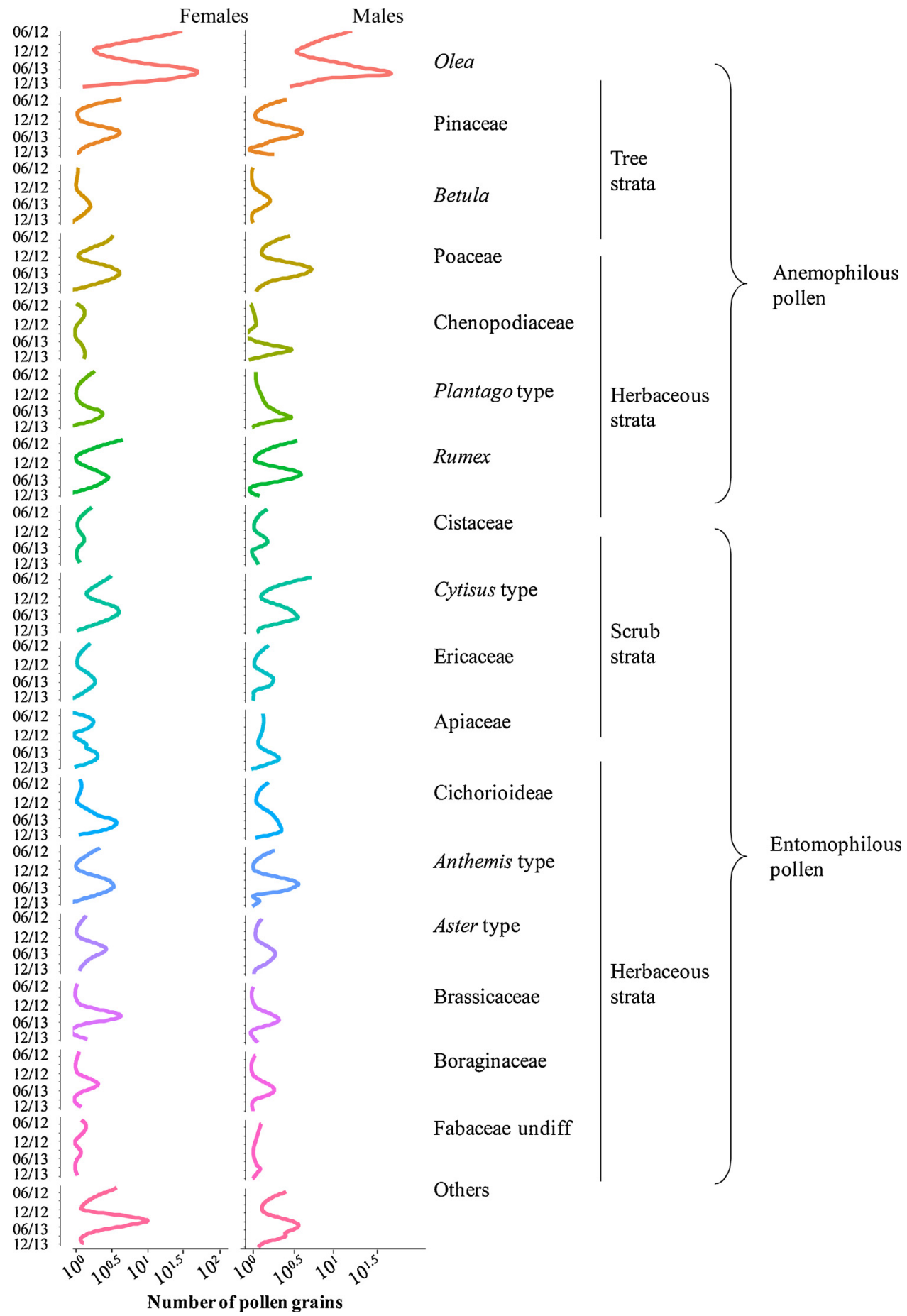

Fig. 3. Number of pollen grains discriminated by type consumed by females and males of Chrysoperla carnea s.l. in the olive grove agroecosystem from April to December 2012 and 2013. Lines represent smooth curves (local polynomial regression method - span $=0.6$ ) of the number of pollen grains consumed during the year.

Cichorioideae in the herbaceous stratum. This result is in accordance with those of Villenave et al. (2005). Moreover, van Rijn et al. (2012) found that $C$. carnea feeding on Asteraceae with accessible extrafloral nectar lived longer and produced eggs; however, Asteraceae without the nectar gave rise to shorter longevities, albeit still longer than with water only. In contrast, none of the Asteraceae tested by Villa et al. (2016a) improved the survival of $C$. carnea adults. This finding suggests that most Asteraceae species may be very important as pollen providers but probably not as nectar providers due to their production of insufficient or inaccessible nectar for many short-tongued insects.
Brassicaceae were moderately consumed in spring 2013 and autumn 2012 and 2013, but the selection index was always negative (Table 2). Boraginaceae were consumed by several individuals, but in a low percentage, and the selection index was always negative. Fabaceae undiff (herbaceous Fabaceae) was moderately consumed in the summer of 2012 but showed a negative index selection in all seasons. This pollen type was previously found in chrysopid guts by Villenave et al. (2005 and 2006). 


\subsubsection{Pollen rarely consumed}

In this study, some pollen types were rarely consumed. In those cases, adults could have inadvertently consumed pollen stuck in nectar or honeydew (Wäckers and van Rijn, 2012) or on other vegetation surfaces. Some of those pollen types were not present in the inventoried patches, but they occur in the region (Flora-on, 2017). In all those cases the percentage of consumed pollen grains was low $\left(O_{i} \%<7.3 \%\right)$, however the proportion of available pollen of some types $\left(\hat{\pi}_{i}\right)$ was 0 (not present in the inventoried patches), and the resulting $D_{i}$ was 1 (maximum selection index). These pollen types were Acacia dealbata, Alnus type, Castanea sativa, Cucurbitaceae, Scabiosa type, Ephedra fragilis type, Helianthemum type, Quercus suber, Juniperus, Polygonum persicaria type, Frangula alnus type, Salix and Urtica dioica type.

Other pollen types were rarely consumed or not consumed at all (the percentage of consumed pollen grains was low with $O_{i} \%<4 \%$ in all cases), although they were available in the environment (high $\hat{\pi}_{i}$ ). In this case, the resulting selection index, $D_{i}$, was generally close to -1 (minimum selection index). These pollen types were Arbutus unedo, Campanula type, Caryophyllaceae, Convolvulaceae, Daphne gnidium type, Geranium, Liliaceae undiff, Lamiaceae, Malva sylvestris, Quercus type, Scrophulariaceae, Cardueae type, Euphorbia type, Jasione type, Hypericum, Orobanchaceae, Rubiaceae, Caprifoliaceae, Ranunculaceae, and Crassula type.

Our results agreed with Villenave et al. (2006), who did not find pollen consumption of Convolvulaceae, Geraniaceae, Cucurbitaceae, Malvaceae or Scrophulariaceae in the Chrysoperla specimens analysed. They pointed out that flowers of these families were closed at dusk, and therefore, their pollen would not be available during that period of activity of Chrysoperla adults. Villenave et al. (2006) also did not find Fagaceae pollen type in the adult guts, which was attributed to the fact that few $C$. carnea were actually captured during the flowering time of Fagaceae (autumn for the area of study). Other pollen types, such as Caprifoliaceae, represented by Lonicera periclymenum L. subsp. hispanica (Boiss. \& Reut.) Nyman, and Ranunculaceae, represented by Ranunculus ollissiponensis Pers. and Ranunculus trilobus Desf. were not consumed in the study areas. Further studies are needed to determine if mechanisms, such as competitive interactions (Wäckers and van Rijn, 2012) with other pollinators or the low availability of some of these pollen types could limit chrysopids from feeding on them, or if they are actually avoided.

Although some pollen types were not consumed, those plant species could offer other resources, such as extrafloral nectar. Proteins supplied by pollen are essential for egg production, but carbohydrate sources are also needed for both egg production and survival (Villa et al., 2016a). For example, Lamium purpureum L. (Lamiaceae) resulted in low egg production but improved the survival of $C$. carnea, probably because pollen was not accessible, but insects could feed on its nectar (Villa et al., 2016a).

\section{Conclusion}

The results of this study indicate that $C$. carnea females and males captured in the olive tree canopy visited scrub vegetation patches to feed on bush and tree pollen belonging to Fabaceae, Pinaceae, Cistaceae or Ericaceae and herbaceous vegetation to feed on Asteraceae, Apicaceae, Brassicaceae, Poaceae, Rumex type or Plantago type. These results are in agreement with Villenave et al. (2005), who found Chrysoperla spp. feeding on both arborescent and herbaceous strata. A high plant diversity in the crop could increase the pollen diversity consumed by $C$. carnea. Interestingly, the results indicated that $C$. carnea fed on a high amount of Olea pollen and raised the question about the potential nutritional value of this pollen for adults. In the present study, C. carnea fed on anemophilous and entomophilous pollen not only during the flowering period but also when flowers were not available, suggesting that they can feed on pollen from vegetation surfaces. Additionally, they did not feed on some abundant plant species. Different mechanisms might be involved, such as unattractive characteristics, competitive exclusion by other pollinators or closed flowers at twilight. Further studies should also address the nutritional composition of the most abundant pollen types found in C. carnea guts. Finally, few studies have addressed the effect of olive grove agroecosystem vegetation on olive tree pests (Villa et al., 2016c). Further studies should address how changes in flowering plant biodiversity affect pest control accomplished by $C$. carnea.

\section{Acknowledgments}

The authors are grateful to the Portuguese Foundation of Science and Technology for financial support through the project EXCL/AGRPRO/0591/2012 "Olive crop protection in sustainable production under global climatic changes: linking ecological infrastructures to ecosystem functions." M.V. thanks FCT, PostDoc grant (SFRH/BPD/ $119487 / 2016)$.

\section{References}

Arambourg, Y., 1984. La fauna entomológica del olivo. Olivae 2, 39-44.

Bento, A., 1999. Contribuição para o estabelecimento de um programa de proteccão integrada contra a traça da oliveira, Prays oleae (Bern.) em Trás-os-Montes. PhD thesis. Universidade de Trás-os-Montes e Alto Douro, Vila Real, Portugal.CAB International [accessed 20/01/2019]. www.cabi.org.

Canard, M., 2001. Natural food and feeding habits of lacewings. In: McEwen, P.K., New, T.R., Whittington, A.E. (Eds.), Lacewings in the Crop Environment. Cambridge University Press, New York, pp. 116-129.

COS, 2007. Carta de Uso e Ocupação do Solo de Portugal Continental para 2007. Instituto Geográfico Portugués (Accessed 20/01/2019). http://mapas.dgterritorio.pt/wms/ $\cos 2007 \mathrm{v} 2$.

Duelli, P., 1984. Dispersal and oviposition strategies in Chrysoperla carnea. In: Gepp, J., Aspöck, H., Hölzel, H. (Eds.), Progess in World's Neuropterology. Graz, pp. 133-145. Flora-on. 2017. http://flora-on.pt/ [Accessed 19 September 2017].

Jones, G.D., 2014. Pollen analyses for pollination research, acetolysis. J. Pollinat. Ecol. 13 (21), 203-217.

Landis, D.A., Wratten, S.D., Gurr, G.M., 2000. Habitat management to conserve natural enemies of arthropod pests in agriculture. Annu. Rev. Entomol. 45, 175-201.

Liolios, V., Tananaki, C., Dimou, M., Kanelis, D., Goras, G., Karazafiris, E., Thrasyvoulou, A., 2016. Ranking pollen from bee plants according to their protein contribution to honey bees. J. Apicul. Res. https://doi.org/10.1080/00218839.2016.1173353.

Manly, B.F.J., McDonald, L.L., Thomas, D.L., McDonald, T.L., Erickson, W.P., 2002. Resource Selection by Animals Statistical Design and Analysis for Field Studies, Second ed. Kluwer Academic Publishers, Dordrecht.

McEwen, P.K., Ruiz, J., 1994. Relationship between non-olive vegetation and green lacewing eggs in a Spanish olive orchard. Antenna 18, 148-149.

Medeiros, M.A., Ribeiro, P.A., Morais, H.C., Castelo Branco, M., Sujii, E.R., SalgadoLaboriau, M.L., 2010. Identification of plant families associated with the predators Chrysoperla externa (Hagen) (Neuroptera: chrysopidae) and Hippodamia convergens Guérin-Menéville (Coleoptera: coccinelidae) using pollen grain as a natural marker. Braz. J. Biol. 70, 293-300.

Monserrat, V.J., Díaz-Aranda, L.M., 1989. Nuevos datos sobre los crisópidos ibéricos (Neuroptera, Planipennia: chrysopidae) boletín Asoc. Esp. Entom. 13, 251-267.

Monserrat, V.J., Marín, F., 1994. Plant subtrate specificity of iberian Chrysopidae (Insecta: neuroptera). Acta Oecológica 15 (2), 119-131.

Moore, P.D., Webb, J.A., Collinson, M.E., 1991. Pollen Analysis. Blackwell Scientific Publications, Oxford.

Mueller-Dombois, D., Ellenberg, H., 1974. Community Sampling: the Relevé Method. Aims and Methods of Vegetation Ecology. John Wiley and Sons, USA, pp. 45-66.

Neuenschwander, P., Michelakis, S., 1980. The seasonal and spatial distribution of adults and larval chrysopids on olive trees in Crete. Acta Oecol. 1, 93-102.

Nunes Morgado, L., Resendes, R., Moura, M., Mateus Ventura, M.A., 2014. Pollen resources used by Chrysoperla agilis (Neuroptera: chrysopidae) in the Azores. Portugal. Eur. J. Entomol. 111 (1), 143-146.

Pantaleoni, R.A., Lentini, A., Delrio, G., 2001. Lacewings in Sardinian olive groves. In: McEwen, P.K., New, T.R., Whittington, A.E. (Eds.), Lacewings in the Crop Environment. Cambridge Univ. Press, New York, pp. 435-446.

Paredes, D., Cayuela, L., Gurr, G.M., Campos, M., 2015. Single best species or natural enemy assemblages? A correlational approach to investigating. BioControl 60, 37-45.

Porcel, M., 2012. Bioecological Study of the Chrysopidae family (Insecta: Neuroptera) in Olive Orchards From a Population Growth and Conservation Perspective. PhD Thesis. Universidad de Granada.

Porcel, M., Ruano, F., Cotes, B., Peña, A., Campos, K., 2013. Agricultural management systems affect the green lacewing community (Neuroptera:chrysopidae) in olive orchards in southern Spain. Environ. Entomol. 42, 97-106.

Principi, M.M., 1991. Lo stato di diapausa negli insetti ed il suo manifestarsi in alcune specie di Crisopidi (Insecta Neuroptera) in dipendenza dell'azione fotoperiodica. Boll. Ist Ent. "G.Grandi" Univ. Bologna 46, 1-30.

R Core Team, 2016. R: a Language and Environment for Statistical Computing. URL:. R Foundation for Statistical Computing, Vienna, Austria. https://www.R-project.org/. 
Resende, A.L.S., Souza, B., Ferreira, R.B., Aguiar-Menezes, E.L., 2017. Flowers of Apiaceous species as sources of pollen for adults of Chrysoperla externa (Hagen) (Neuroptera). Biol. Control 106, 40-44.

Valdés, B., Diez, M.J., Fernandez, I., 1987. Atlas polínico de Andalucía occidental. Instituto de Desarrollo Regional. University of Sevilla, Sevilla.

van Rijn, P.C.J., 2012. The suitability of field margin flowers as food source for Chrysoperla lacewings. In: Holland, J., Gerowitt, B., Alomar, O., Bianchi, F., Eggenschwiler, L., van Helden, M., Moonen, C., Poehling, H.M., Rossing, W. (Eds.), Working Group "Landscape Management for Functional Biodiversity". 5th Meeting IOBC/WPRS of the Working Group "Landscape Management for Functional Biodiversity", pp. 213-216 Lleida, Spain, 75.

Villa, M., Santos, S.A.P., Benhadi-Marin, J., Mexia, A., Bento, A., Pereira, J.A., 2016a. Life-history parameters of Chrysoperla carnea fed on spontaneous plant species and insect honeydews: importance for conservation biological control. BioControl. https://doi.org/10.1007/s10526-016-9735-2.

Villa, M., Santos, S.A.P., Marrão, R., Pinheiro, L.A., López-Saez, J.A., Mexia, A., Bento, A. Pereira, J.A., 2016b. Syrphids feed on multiple patches in heterogeneous agricultural landscapes during the autumn season, a period of food scarcity. Agric. Ecosyst. Environ. 233, 262-269.
Villa, M., Marrão, R., Mexia, A., Bento, A., Pereira, J.A., 2016c. Are wild flowers and insect honeydews potential food resources for adults of the olive moth, Prays oleae? J. Pest Sci. 90, 185-194.

Villenave, J., Deutsch, B., Lode, T., Rat-Morris, E., 2006. Pollen preference of the Chrysoperla species (Neuroptera: chrysopidae) occurring in the crop environment in western France. Eur. J. Entomol. 103, 771-777.

Villenave, J., Thierry, D., Al Mamun, A., Lodé, T., Rat-Morris, E., 2005. The pollens consumed by common green lacewings Chrysoperla spp. (Neuroptera: chrysopidae) in cabbage crop environment in western France. Eur. J. Entomol. 102, 547-552.

Wäckers, F., van Rijn, P.C.J., 2012. Pick and mix: selecting flowering plants to meet the requirements of target biological control insects. In: Gurr, G.M., Wratten, S.D., Snyder, W.E., Read, D.M.Y. (Eds.), Biodiversity and Insect Pests: Key Issues for Sustainable Management, first ed. John Wiley \& Sons, Ltd, Chichester, UK, pp. 139-165.

Wood, S.N., 2011. Fast stable restricted maximum likelihood and marginal likelihood estimation of semiparametric generalized linear models. J. R. Stat. Soc. B 73 (1), 3-36.

Zuur, A.F., 2012. A Beginner's Guide to Generalized Additive Models With R. Highland Statistics Ltd., Newburgh. 